\title{
Evaluation of Rock Bolt Support for Polish Hard Rock Mines
}

\author{
Krzysztof Skrzypkowski ${ }^{1, *}$ \\ ${ }^{1}$ AGH University Science and Technology, Faculty of Mining and Geoengineering, \\ A. Mickiewicza Av. 30, 30-059 Krakow, Poland
}

\begin{abstract}
The article presents different types of rock bolt support used in Polish ore mining. Individual point resin and expansion rock bolt support were characterized. The roof classes for zinc and lead and copper ore mines were presented. Furthermore, in the article laboratory tests of point resin rock bolt support in a geometric scale of 1:1 with minimal fixing length of $0.6 \mathrm{~m}$ were made. Static testing of point resin rock bolt support were carried out on a laboratory test facility of Department of Underground Mining which simulate mine conditions for Polish ore and hard coal mining. Laboratory tests of point resin bolts were carried out, especially for the ZGH Bolesław, zinc and lead "Olkusz - Pomorzany" mine. The primary aim of the research was to check whether at the anchoring point length of $0.6 \mathrm{~m}$ by means of one and a half resin cartridge, the type bolt "Olkusz - 20A" is able to overcome the load.The second purpose of the study was to obtain load - displacement characteristic with determination of the elastic and plastic range of the bolt. For the best simulation of mine conditions the station steel cylinders with an external diameter of $0.1 \mathrm{~m}$ and a length of $0.6 \mathrm{~m}$ with a core of rock from the roof of the underground excavations were used. Key words - point resin rock bolt support, roof class, ore mining.
\end{abstract}

\section{Introduction}

In Poland the underground exploitation of ore deposits is carried out in two regions. Wherein the primary source of lead are zinc-lead ores deposits of Mississippi Valley type in the SilesianCracow region and copper ore deposits in the Fore-Sudetic Monocline. The exclusive primary sources of zinc in Poland are zinc and lead ore deposits of Missisippi Valley type in the Triassic dolomites of the Silesian-Cracow region. In the last year there were the following deposits operated in the Olkusz region, i.e. Olkusz, Pomorzany and Klucze I $[4,5]$. It is worth mentioning that the mentioned deposits are explored in the only one underground zinc and lead mine „Olkusz-Pomorzany” belonging to ZGH Bolesław S.A. in Bukowno. Copper ores are excavated in the Fore-Sudetic Monocline deposits, which contains many accompanying minerals. Currently underground exploitation is carried out in three mines "Rudna", "Polkowice - Sieroszowice” and „Lubin” of Legnica-Głogów Copper District (LGOM), that belong to KGHM Polish Copper SA. The basic type of rock mass reinforcement method for both preparatory and operational excavations in underground metal ore mines, both in Poland

* Corresponding author: skrzypko@agh.edu.pl 
and in different countries across the world, is the expansion shell or adhesive-bonded rock bolt $[3,6,8]$. The annual consumption of rock bolt supports in Polish ore mining is more than 3 million units (Tab. 1).

Table 1. Division of rock bolt support in Polish ore mining with particular emphasis on the annual consumption

\begin{tabular}{|c|c|c|c|}
\hline \multicolumn{2}{|r|}{ Criterion of division } & \multirow{2}{*}{$\begin{array}{l}\text { ZGH Boleslaw S.A. } \\
\text { zinc and lead } \\
\text { „Olkusz - } \\
\text { Pomorzany" mine }\end{array}$} & \multirow{2}{*}{$\begin{array}{c}\text { KGHM } \\
\text { Polish Copper S.A. } \\
\text { Copper "Rudna", } \\
\text { "Polkowice - } \\
\text { Sieroszowice" } \\
\text { and „Lubin" mines }\end{array}$} \\
\hline Group & Subgroup & & \\
\hline \multirow{3}{*}{$\begin{array}{l}\text { Mechanism of } \\
\text { action rock } \\
\text { bolts }\end{array}$} & $\begin{array}{l}\text { 1. Grouted - installd in the rock } \\
\text { mass by means of various types } \\
\text { of cement binders or resin } \\
\text { cartridges (the annual } \\
\text { consumption in thousands) } \\
\end{array}$ & 130 & about 1500 \\
\hline & $\begin{array}{l}\text { 2. Mechanical - installed in the } \\
\text { rock mass by means of shell head } \\
\text { spread out inside a borehole (the } \\
\text { annual consumption in } \\
\text { thousands) }\end{array}$ & They are not used & about 1500 \\
\hline & $\begin{array}{l}\text { 3. Friction - acting on the } \\
\text { principle of friction occurring } \\
\text { between bolt and borehole }\end{array}$ & They are not used & (sporadically only for tests) \\
\hline \multirow[t]{3}{*}{$\begin{array}{l}2 . \\
\text { Type of } \\
\text { material }\end{array}$} & $\begin{array}{l}\text { 1. Steel - in the form of rods, } \\
\text { pipes, sheets, strings and cables }\end{array}$ & Only rods & $\begin{array}{l}\text { Rods and cables } \\
\text { (sporadically pipes only for } \\
\text { tests) }\end{array}$ \\
\hline & 2. Wooden rods & They are not used & They are not used \\
\hline & $\begin{array}{l}\text { 3. Composite materials in the } \\
\text { form of rods, pipes and strings }\end{array}$ & They are not used & (sporadically only for tests) \\
\hline \multirow[t]{2}{*}{$\begin{array}{l}3 . \\
\text { Method of } \\
\text { mounting }\end{array}$} & $\begin{array}{l}\text { 1. Continuous - the bolt is fixed } \\
\text { in the hole along its entire length } \\
\text { by applying adhesive resin } \\
\text { catridges or a suitable cement } \\
\text { binder and on the friction } \\
\text { principle }\end{array}$ & Full column resin bolts & $\begin{array}{l}\text { Full column resin bolts and } \\
\text { Full column slow }(120 \mathrm{~s}) \\
\text { and fast }(30 \mathrm{~s}) \text { resin } \\
\text { combination bolts. } \\
\text { Additionally suitable } \\
\text { cement binder for cable } \\
\text { bolts }\end{array}$ \\
\hline & $\begin{array}{l}\text { 2. Point - this type is } \\
\text { characteristic for wedge, jaw or } \\
\text { short encapsulated bolts, it } \\
\text { allows the bolt be pre-tensioning }\end{array}$ & They are not used & $\begin{array}{l}\text { Expansion (mechanical) } \\
\text { bolts }\end{array}$ \\
\hline \multirow{2}{*}{$\begin{array}{l}4 . \\
\text { Length }\end{array}$} & 1. Short, $[\mathrm{m}]$ & 1.6 & $1.2 ; 1.6 ; 1.8 ; 2.2 ; 2.6$ \\
\hline & 2. Long, $[\mathrm{m}]$ & $\begin{array}{l}2.7 \text { (about } 300 \text { units) in } \\
\text { form of steel rods }\end{array}$ & $\begin{array}{l}3.5 ; 5.2 ; 7 \text { (about } 270000 \\
\text { units) in form of steel } \\
\text { connected rods and cables }\end{array}$ \\
\hline \multirow[t]{2}{*}{$\begin{array}{l}5 . \\
\text { Installation }\end{array}$} & $\begin{array}{l}\text { 1. Self-propelled drilling-bolting } \\
\text { machine (the annual } \\
\text { consumption in thousands) }\end{array}$ & $6 \div 7$ & 3000 \\
\hline & $\begin{array}{l}\text { 2. Manual bolting (the annual } \\
\text { consumption in thousands) }\end{array}$ & 123 & They are not used \\
\hline
\end{tabular}

It is worth mentioning that, exploitation of zinc and lead in "Olkusz - Pomorzany" mine is carried out at depth of about $100 \mathrm{~m}$ below ground surface whereas exploitation of copper in Legnica-Głogów Copper District (LGOM) mines is carried out at depth over $1000 \mathrm{~m}$ up 
to $1200 \mathrm{~m}$ below ground surface. Therefore in the "Olkusz - Pomorzany" mine there are only rigid bolts used with satisfactory strength and only failing, when taking over the load near the limit of strength of bolt rod, with relatively small deformation capacity, whilst in the copper mines there are used rigid and yielding bolts capable of carrying significant deformation, with relatively low carrying capacity and also more and more there are used energy-absorbing of dynamic load bolts, characterized by high load carrying capacity and the ability to carry relatively high displacement and deformation.

\section{Choice of rock bolt support}

The variety of conditions in which the rock bolt support is used makes it suitable for securing the stability of the excavation or as reinforcement of existing rock bolt support [3]. Choice of rock bolt support in „Olkusz - Pomorzany” mine is based on the determination of roof's class which is determined on the basis of the results of geomechanical tests and on the basis evaluation of weakness factor of rock mass ,c" carried out by an expert [4]. There are five classes of the roof, for which a specific parameters are determined for application of rock bolt support; way of fixing (point or continuous), the mechanism of action (resin, expansion or friction), the length of bolts, spacing in rows, with the additional security and, above all, cross-sectional shape of excavation (Tab. 2).

Table 2. Roof class for zinc and lead ores

\begin{tabular}{|c|c|c|c|c|c|}
\hline $\begin{array}{c}\text { Roof } \\
\text { class }\end{array}$ & Description & $\begin{array}{c}\text { Compressive } \\
\text { strength Rc } \\
\text { [MPa] }\end{array}$ & $\begin{array}{c}\text { Rock mass } \\
\text { weakening } \\
\text { coefficient ,c” }\end{array}$ & $\begin{array}{c}\text { Shape of } \\
\text { the } \\
\text { excavation }\end{array}$ & Support type \\
\hline I & $\begin{array}{c}\text { very hard } \\
\text { rocks }\end{array}$ & at least 70 & more than 0.9 & $\begin{array}{c}\text { rectangular } \\
\text { or } \\
\text { trapezoidal }\end{array}$ & $\begin{array}{l}\text { rock bolts or } \\
\text { without support }\end{array}$ \\
\hline II & $\begin{array}{c}\text { strong } \\
\text { stratified } \\
\text { rocks }\end{array}$ & $50-70$ & $0.7-0.9$ & $\begin{array}{c}\text { rectangular } \\
\text { or } \\
\text { trapezoidal }\end{array}$ & $\begin{array}{l}\text { expansion or point } \\
\text { resin rock bolts }\end{array}$ \\
\hline III & $\begin{array}{c}\text { fragile } \\
\text { stratified } \\
\text { rocks }\end{array}$ & $30-50$ & $0.5-0.7$ & $\begin{array}{c}\text { flat or oval } \\
\text { roof }\end{array}$ & $\begin{array}{l}\text { expansion or point } \\
\text { resin rock bolts }\end{array}$ \\
\hline IV & $\begin{array}{c}\text { weak rocks } \\
\text { V }\end{array}$ & $20-30$ & $0.4-0.55$ & $\begin{array}{c}\text { point resin or full } \\
\text { column resin rock } \\
\text { bolts and steel } \\
\text { lagging }\end{array}$ \\
\hline V & $\begin{array}{c}\text { very weak } \\
\text { rocks }\end{array}$ & less than 20 & less than 0.4 & oval roof & $\begin{array}{l}\text { arch yielding } \\
\text { support }\end{array}$ \\
\hline
\end{tabular}

The length of roof rock bolt is at least $1.6 \mathrm{~m}$. The basic net bolting is a diagram $1 \times 1 \mathrm{~m}$ to $1.2 \times 1.2 \mathrm{~m}$. Side walls of excavations more than $4.5 \mathrm{~m}$ are subjected to bolting, wherein the first row is made $4.5 \mathrm{~m}$ from the floor; the length of side walls rock bolt is at least $1 \mathrm{~m}$.

Selection of excavation support in copper ore mining is performed by the Head of the Mining Works Department on the basis of knowledge of geological and mining conditions (Tab. 3). In practice, this insight is implemented by determining the roof class, in accordance with the instruction $[2,10]$ used by the KGHM, developed by an expert. The classification of the roof rocks is based on the hierarchy of parameters' validity, which basically determines the stability of the roof of mining excavations. These parameters include: roof delamination (divisibility in the vertical direction), density of mineralized fractures in the roof of excavations, degree of fault, average throw of fault, tensile strength. Individual parameters are obtained 
as a result of analysis of drill cores, analysis of drilling hole walls by means of endoscopes, analysis of exposures, and research on geomechanical properties of rocks. In addition, correction coefficients have been introduced to determine the rock of the roof, taking into account the impact of the open width of the working space and the method of roof management. Furthermore, when selecting the rock bolt support, the compressive strength, intended use projected dimensions of the excavation and the experience in the application of rock bolt support are taken into account. In the case of long-term excavations, grouted-monted bolts are preferable, more resistant to corrosion and do not require obtaining and then maintaining a high pre-tension.

Table 3. Roof class for copper ores

\begin{tabular}{|c|c|c|c|c|c|c|c|c|c|c|}
\hline \multirow[b]{5}{*}{ 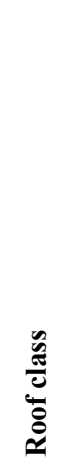 } & \multirow[b]{5}{*}{ 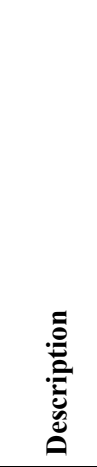 } & \multirow{5}{*}{ 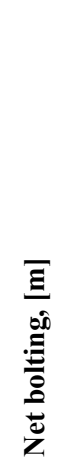 } & \multicolumn{5}{|c|}{$\begin{array}{l}\text { Maximal expansion of excavations in the } \\
\text { developed phase of exploitation }\end{array}$} & \multirow{5}{*}{ 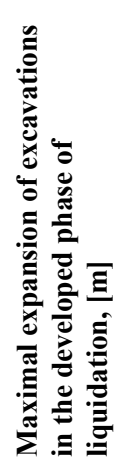 } & \multirow{5}{*}{ 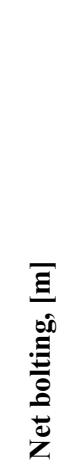 } & \multirow{5}{*}{ 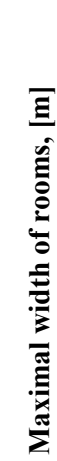 } \\
\hline & & & \multicolumn{5}{|c|}{ Heigth of room, [m] } & & & \\
\hline & & & $\begin{array}{c}\text { up to } \\
2.0\end{array}$ & $\begin{array}{c}\text { up to } \\
5.0\end{array}$ & $\begin{array}{c}\text { up to } \\
7.0\end{array}$ & $\begin{array}{c}\text { up to } \\
7.0\end{array}$ & $\begin{array}{c}\text { from } \\
7.0\end{array}$ & & & \\
\hline & & & \multicolumn{5}{|c|}{ Minimal length of rock bolts, [m] } & & & \\
\hline & & & 1.2 & 1.6 & 1,8 & 2.2 & 2.6 & & & \\
\hline I & $\begin{array}{l}\text { weak } \\
\text { rocks }\end{array}$ & $\begin{array}{l}1 \\
\times \\
1\end{array}$ & & 7.0 & 8.0 & 9.0 & 10.0 & 15.0 & $\begin{array}{l}1 \\
\times \\
1\end{array}$ & 6.0 \\
\hline II & $\begin{array}{c}\text { averag } \\
\text { e-hard } \\
\text { rocks } \\
\text { I }\end{array}$ & $\begin{array}{c}1.5 \\
\times \\
1.5\end{array}$ & & 9.0 & 10.0 & 11.0 & 12.0 & 17.0 & $\begin{array}{l}1 \\
\times \\
1\end{array}$ & 7.0 \\
\hline III & $\begin{array}{c}\text { averag } \\
\text { e-hard } \\
\text { rocks } \\
\text { II }\end{array}$ & $\begin{array}{c}1.5 \\
\times \\
1.5\end{array}$ & 8.0 & 10.0 & 12.0 & 13.0 & 14.0 & 18.0 & $\begin{array}{c}1.5 \\
\times \\
1.5\end{array}$ & 7.0 \\
\hline IV & $\begin{array}{l}\text { hard } \\
\text { rocks }\end{array}$ & $\begin{array}{l}2 \\
\times \\
2\end{array}$ & 9.0 & 12.0 & 14.0 & 16.0 & 18.0 & 20.0 & $\begin{array}{l}2 \\
\times \\
2\end{array}$ & 7.0 \\
\hline $\mathrm{V}$ & $\begin{array}{l}\text { very } \\
\text { hard } \\
\text { rocks }\end{array}$ & $\begin{array}{l}2 \\
\times \\
2\end{array}$ & 10.0 & 13.0 & 15.0 & 17.0 & 20.0 & 25.0 & $\begin{array}{l}2 \\
\times \\
2\end{array}$ & 8.0 \\
\hline & Exploit: & on roo & & & & & & & $\begin{array}{l}\text { Drift } \\
\text { exca }\end{array}$ & \\
\hline
\end{tabular}

In mining fields, where the period from the completion of the excavation to its liquidation is relatively short, expansion bolts are more often used, which due to the less time consuming construction, allow for greater bolting efficiency [1]. Examples of bolting diagrams for zinc and lead and copper ore mining are shown in Figures 1 and 2. 


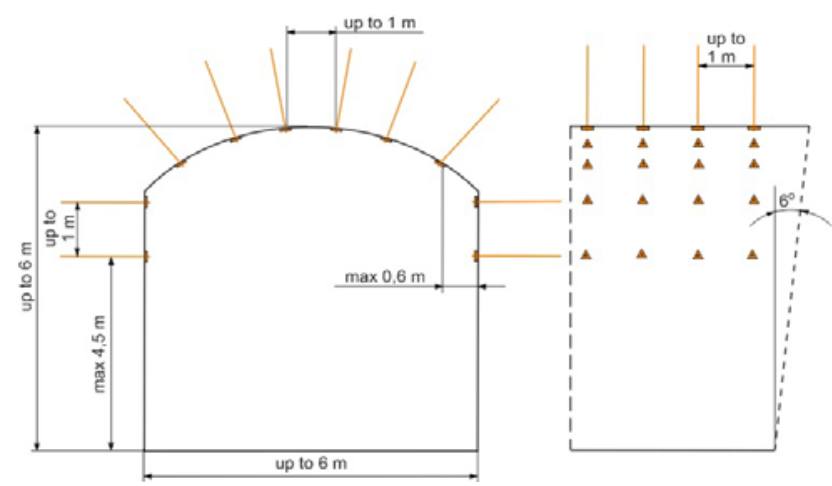

Fig. 1. Room support with oval roof by means of rock bolt support in zinc and lead ore mine

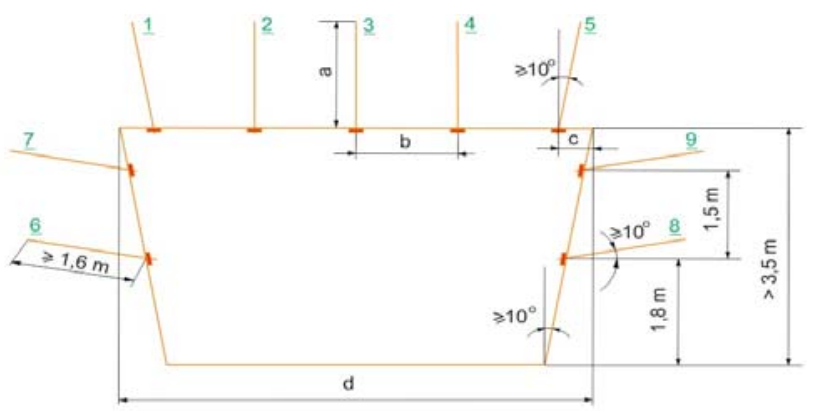

Fig. 2. Room support by means of rock bolt support for drift excavation with height more than $3.5 \mathrm{~m}$ in copper ore mine: $\mathrm{a}$ - length of bolt, $\mathrm{b}$ - net bolting, $\mathrm{c}$ - maximal distance from side wall $(\mathrm{c} \leq \mathrm{d})$, $\mathrm{d}-$ width of drift, $1-9-$ bolt numbers

\section{Laboratory test facility}

Static tests of point resin rock bolts were carried out at the laboratory test facility in simulated mining conditions, in particular for the zinc and lead "Olkusz - Pomorzany" mine. Studies were carried out using a consistent methodology. In the static load mode, the rock bolts were stretched and broken by the use of maximum force resulting from the power of the pump. Displacement and force sensors were connected to a QuantumX MX840 universal measuring amplifier via 15-pin plugs. During the tensile process the results of force and displacement measurements were recorded continuously by a program specialized in the field of measurement technology - known as „CATMAN-EASY” [9]. Resin rock bolts type "Olkusz 20A" used in the laboratory tests constitute the basis of mining excavation supports in underground zinc and lead "Olkusz - Pomorzany" mine. Rock bolt type "Olkusz 20 A" was modified for the needs of the conducted experience and consists of a ribbed bar with a $1.6 \mathrm{~m}$ length which has a diameter of $20 \mathrm{~mm}$, at one end has a thread with M20 (Fig. 3a) and circular shaped bearing plate with a diameter of $150 \mathrm{~mm}$ and a thickness of $6 \mathrm{~mm}$ (Fig. 3c). The height of the bearing plate was $24.8 \mathrm{~mm}$, made of steel grade St3SAL or 18G2A. The other end of the rod is angled $30-35^{\circ}$ in order to improve mixing of the resin. Additionally bolt was equipped with connecting sleeve (Fig. 3d) and threated extension (Fig. 3b). This configuration made it possible to install the bolt without a nut. Support's rods are made of stainless steel "EPSTAL", B500SP steel grade, which is characterized by the following parameters: yield strength $(\mathrm{Re})$ of $500 \mathrm{MPa}$ to $625 \mathrm{MPa}$; ratio of tensile strength to yield strength $(\mathrm{Rm} / \mathrm{Re})$ from 1.15 to 1.35 ; percentage elongation (A5) a minimum of $16 \%$ and the percentage elongation at maximum force (Agt) equal to at least $8 \%$. 
a)

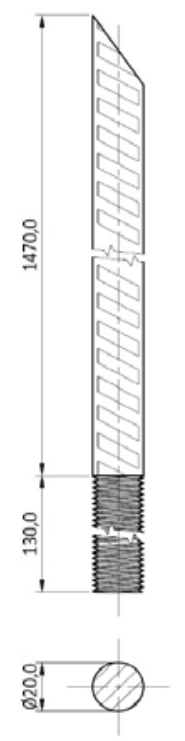

b)

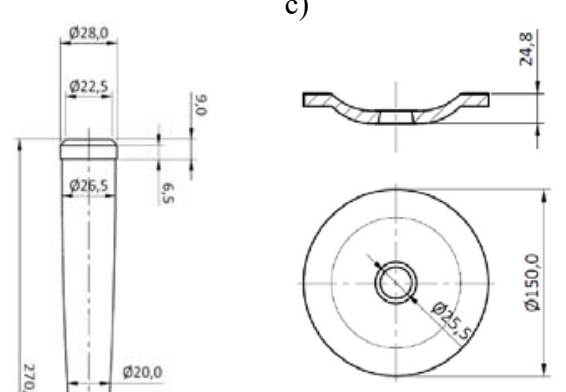

d)
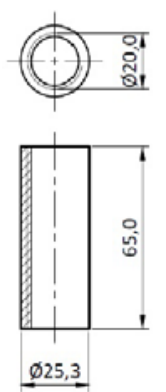

Fig. 3. Elements of the resin rock bolt support type "Olkusz 20A": a) bolt rod, b) threated extension, c) shaped bearing plate, profiled with a ring, d) connecting sleeve

a)

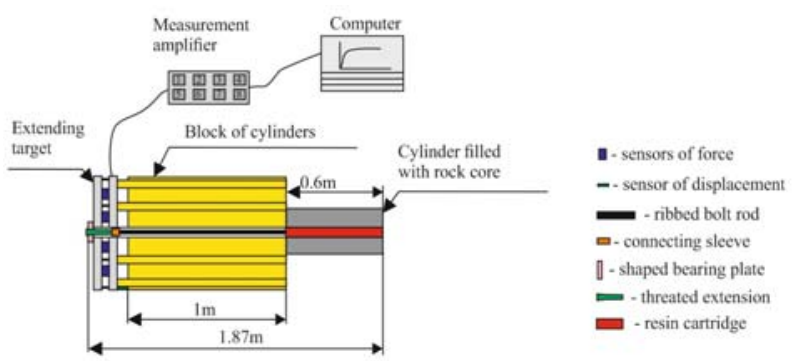

b)

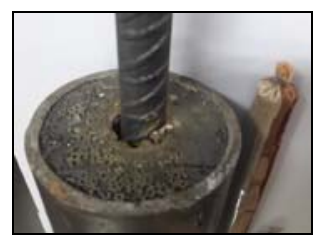

c)

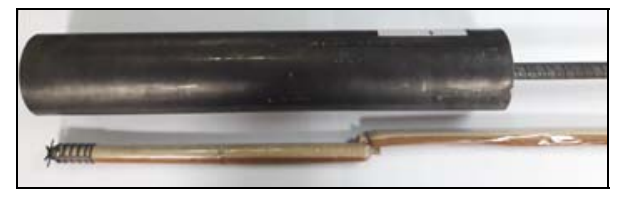

Fig. 4. Arrangement of sensors and elements of rock bolt support on the laboratory test facility; a) rock bolt support with a length $1.87 \mathrm{~m}, \mathrm{~b}$ ) rock core with a diameter $0.028 \mathrm{~m}$, c) resin cartridge with a length $0.4 \mathrm{~m}$ (photo: K. Skrzypkowski)

In order for laboratory studies to best satisfy mining conditions, rock cores obtained from underground excavations were used (Fig. 4). Rock cores (dolomites) had holes with a diameter $0.028 \mathrm{~m}$ (Fig. 4a) and characterized compressive strength up to $100 \mathrm{MPa}$. Bolt was installed into core by means of one and a half resin cartridge with a length of $0.6 \mathrm{~m}$. Resin cartridge type "Lokset" has a length $0.4 \mathrm{~m}$ and diameter $0.24 \mathrm{~m}$ (Fig. 4b). It consists of binding compound, a hardener and a plastic coating. In addition, there is an overlay at one end of the cartridge, the task of which is to keep the cartridge in the hole so that it does not fall out. 


\subsection{Load-displacement characteristics of point resin rock bolt}

The aim of this study was to obtain load-displacement characteristics of point resin rock bolt on the basis of which it will be possible to determine individual phases of load and deformation of the bolt. During tests the results of force and displacement characteristics were recorded continuously and visualization and evaluation of the measurement were tracked on-going. In addition, after the tests were completed, reports documenting the results of the measurements were created and then stored as an ASCII file extension. Examples of the characteristic parameters obtained in the tests are shown in Figure 5.

a)

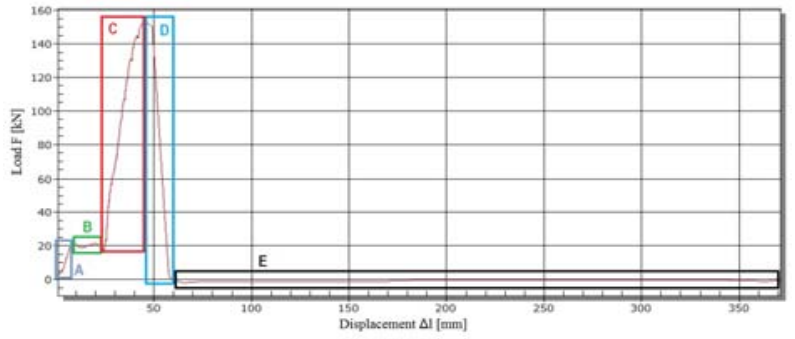

b)

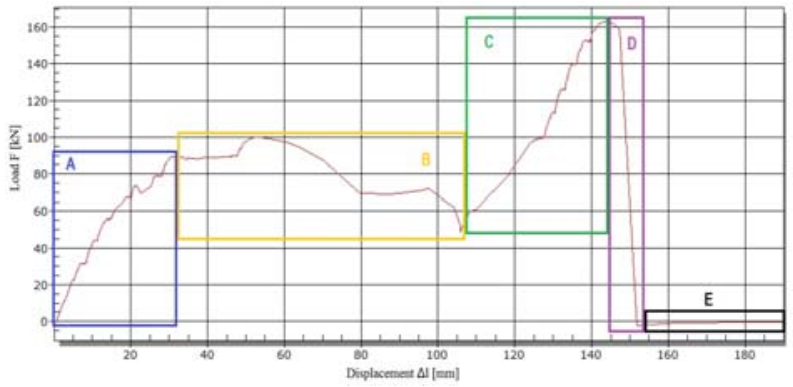

c)

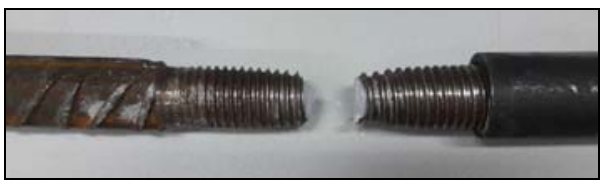

Fig. 5. Load displacement characteristic of point resin rock bolt support: a) bolt no 1, b) bolt no 2 , c) break on the thread of rod bolt (photo by K. Skrzypkowski)

The obtained characteristics were divided into five phases, visible in Figure 5a (A, B, C, $\mathrm{D}, \mathrm{E})$. The marked area $\mathrm{A}$ together with the area $\mathrm{C}$ constitutes the whole and shows a similar growth character of the pull out force, relative to the displacement. The growth trend is disturbed by slipping the bearing plate - phase $\mathrm{B}$, which was observed during the test. For a maximum tensile force equal $153 \mathrm{kN}$, the displacement was $45 \mathrm{~mm}$. A sudden drop of load (phase D) was caused by pulled out the bolt. The next phase $\mathrm{E}$ is the total extension of the bolt from the hole. The load-displacement characteristic of the Olkusz-20A bolt number 2 (Fig. 5b) has been divided into five characteristic parts. The tensile force diagram in phase $\mathrm{A}$ is presented in accordance with the reference to tensile characteristics of the bolt. In the initial phase B, smoothing occurs, which is caused by the notch of the bearing plate which was observed in time. Then a slight increase is noticeable, followed by a drop in load relative to the increasing of displacement. This is due to the extension of the bolt from the hole, which was also noticed during the test. In phase $\mathrm{C}$, the breaking force increases, up to the 
critical value, which was $162 \mathrm{kN}$ and the bolt breaks at the thread location (Fig. 5c). Phase $\mathrm{D}$ presents the breaking of the bolt, while phase E shows the extension of the broken part.

\section{Conclusions}

At present rock bolt support in underground zinc and lead „Olkusz - Pomorzany” mine is installed in the bolt holes made by means of self-propelled drilling - bolting machines type SWK-2 Hz and Robolt 320-22C. Drilling bolt holes is one of the most dangerous operations, as is done with an unprotected roof of the excavation. The excavations, in which the roof is very fragile also is used manual bolting. W 2017 it was used about 123000 resin rock bolts support „Olkusz 16A” type at manual bolting and about 7000 resin rock bolts support „Olkusz $20 A$ ” type at self-propelled drilling-bolting mining machines. For bolts „Olkusz 16A” type, holes are drilled with a diameter of $35 \mathrm{~mm}$. For fixing rod is used at least two loads of resin „Lokset” type with a diameter of $30 \mathrm{~mm}$ and length $600 \mathrm{~mm}$ for which the gel time is equal 2 minutes. Wherein for bolts „Olkusz 20A” type in the roof are drilled holes with a diameter of $33 \mathrm{~mm}$. For fixing the rod typically are used four resin cartridges „Lokset” type, which have a diameter of $24 \mathrm{~mm}$ and length $400 \mathrm{~mm}$ for which is gel time is equal 30 seconds.

According to Polish Standard Norm [7] capacity of resin bolts in underground exploitation of ore deposits of lead and zinc should be at least $90 \mathrm{kN}$. Control of the bolting consists of a pull out tests with load of force up to $40 \mathrm{kN}$. In laboratory tests, the point resin rock bolts were fixed at the length of $0.6 \mathrm{~m}$. Based on the obtained characteristics, it is possible to state that the support has taken over the minimum required load. This means that it is possible to propose a modification of the bolting technology, which would mean point mounting instead of the entire length in the bolting holes. Some restriction resulting from geological conditions. It should be remembered that in „Olkusz - Pomorzany” mine, roofs of excavations (room) are represented very often by oxidized and strongly fractured ore bearing dolomites.

\section{Acknowledgements}

The study was carried out within the framework of statutory work no. 11.11.100.005.

\section{References}

1. C. Matusz, K. Szczerbiński, Cuprum. 66, 1, (2013)

2. J. Butra, Eksploatacja złoża rud miedzi $w$ warunkach zagrożenia tapaniami $i$ zawałami. Wydawnictwo KGHM CUPRUM sp. z o.o. Wrocław (2010)

3. K. Skrzypkowski, E3S Web of Conferences. 29, (2018)

4. K. Skrzypkowski, Interdisciplinary Topics in Mining and Geology. M. Hardygóra, J. BacBromowicz, J. Drzymała (eds.). Wrocław (2016)

5. K. Skrzypkowski, W. Korzeniowski W, Selected issues related to mining and clean coal technology. M. Borowski, J. Swolkień (eds.). Kraków (2016)

6. K. Skrzypkowski, W. Korzeniowski, K. Zagórski, P. Dudek, SGeM. 39, 3 (2017)

7. Polish Standard Norm - PN-G-15091 - Mining bolts. Requirements. (1998)

8. W. Korzeniowski, K. Skrzypkowski, K. Zagórski, SGeM. 39, 1 (2017)

9. W. Korzeniowski, K. Skrzypkowski, Ł. Herezy, Arch. Min. Sci. 60, 1 (2015)

10. W. Pytel, Geomechaniczne problemy doboru obudowy kotwowej dla wyrobisk górniczych. Wydawnictwo KGHM CUPRUM sp. z o.o. Wrocław (2012) 